\title{
Acid precipitation: Its role in the alkalization of a lake in Michigan ${ }^{1}$
}

\section{Peter Kilham ${ }^{2}$}

Division of Biological Sciences, University of Michigan, Ann Arbor 48109

\begin{abstract}
The watershed of Weber Lake in northern lower Michigan has experienced a nearly .20fold increase in proton loading from acid precipitation in the past 25 years. But, owing to alkalinity production by biologically mediated processes (nitrate uptake by plants and sulfate reduction by bacteria) and increased rates of carbonate weathering, acid precipitation has doubled the alkalinity, raised the equilibrium $\mathrm{pH}$, and made this soft-water seepage lake more eutrophic.

An acid-base budget for Weber Lake and its watershed was constructed from the difference between bulk precipitation input and lake water output. Strict application of the first law of thermodynamics and the principle of electroneutrality permits the calculation of the acidbase budget from the input-output budget. The acid-base budget indicates that alkalinity production resulting from nitrate uptake and sulfate reduction is sufficient to completely neutralize the hydrogen ions entering the system from acid precipitation (including biologically mediated hydrogen ion production). The acid-base budget shows that the alkalinity of Weber Lake has doubled primarily as a result of increased rates of weathering in the watershed. Weathering rates have increased as an indirect result of acid precipitation.
\end{abstract}

Acid precipitation is a major environmental problem. Over the past 25 years the acidity of rain and snow falling on eastern North America and northern Europe has increased markedly (see Likens 1976; Likens et al. 1979; Dochinger and Siliga 1976). Lake acidification is occurring in geographic areas underlain by siliceous bedrocks (called sensitive areas because of the poor buffering capacity of the lakes and their watersheds: Likens et al. 1979). Fish have been completely eliminated from many lakes in such regions where the $\mathrm{pH}$ has dropped below 5 (Bcamish et al. 1975; Schofield 1976). Lake acidification also changes the species composition of phytoplankton and zooplankton communities (Almer et al. 1978). Fortunately, because carbonate-rich bedrocks are widespread in North America and Europe, nonsensitive well

I This work was supported by the University of Michigan Biological Station and NSF grant G-OCE78-27016 (Oceanography Section) to P. and S. S. Kilham.

${ }^{2}$ I held a NSF Science Faculty Professional Development Award (SPI-7914932) at The Ecosystems Center, Marine Biological Laboratory, Woods IIole, Massachusetts, during part of the time this study was conducted. buffered areas predominate. Because it is generally assumed that acid precipitation falling on nonsensitive regions is quickly neutralized, the effects of this process have not been studied and remain virtually unknown. I will show here that acid precipitation appears to be having a marked effect on aquatic ecosystems in nonsensitive areas. In these regions acid precipitation is making lakes more alkaline rather than more acidic. Increasing alkalinity, like increasing acidity, represents a drastic environmental change.

Weber Lake is a soft-water seepage lake in a nonsensitive region of northern lower Michigan that has doubled in alkalinity over the past 30 years. Since 1956 the proton loading from acid precipitation at Weber Lake has increased nearly 20 -fold (this study; Cogbill and Likens 1974), and acid precipitation appears to play a major role in determining the present summertime alkalinity of the lake. Because this is to my knowledge the first reported case of lake alkalization occurring as a consequence of acid precipitation, I present several theoretical arguments in support of the techniques of data analysis used. The present alkalinity of Weber Lake is primarily the result of enhanced rates of carbonate weathering in the drainage ba- 
sin caused by a slight lowering of the soil $\mathrm{pH}$ due to acid precipitation and of the neutralization of $\mathrm{H}^{+}$from all sources by $\mathrm{OH}^{-}$(alkalinity) resulting from biologically mediated transformations in the biogeochemical cycles of nitrogen and sulfur. Most of the nitrogen and sulfur entering a system such as this comes from acid precipitation. Hemond (1980) and I independently concluded that biologically mediated $\mathrm{OH}^{-}$production in an ecosystem receiving acid precipitation can neutralize most if not all of the $\mathrm{H}^{+}$entering or biologically produced within a system. He studied Thoreau's Bog, Massachusetts, with a $\mathrm{pH}$ of 3.8 . The $\mathrm{pH}$ range at Weber Lake is 7.2-8.2.

Hooper (1954), the first limnologist to study Weber Lake, observed an unusual negative heterograde distribution of $\mathrm{pH}$ during summer stagnation from 1950 through 1952 (see also Hutchinson 1957, p. 686). We revisited the lake in July 1979 in the hope of extending Hooper's observations, but the lake had changed. Not only was it twice as alkaline, but it also had positive heterograde distributions of $\mathrm{pH}$ and oxygen.

I thank R. F. Stallard, R. W. Howarth, S. S. Kilham, J. T. Lehman, C. A. Kelly, R. H. Hesslein, and F. F. Hooper for comments and suggestions. S. M. Pollack, P. W. Adams, J. R. Boyle, H. A. Crum, and other faculty, students, and staff assisted at the University of Michigan Biological Station (UMBS). Early drafts of the paper were reviewed by $\mathrm{P}$. G. Brewer, R. S. Keir, F. T. Manheim, J. M. Melillo, and B. J. Peterson. D. M. Docauer, G. L. Krausse, and K. A. Johansen helped with the chemical analyses.

\section{Materials and methods}

Lake sampling-Water was collected at 2-m intervals with a 4-liter Van Dorn sampler (Wildco Wildlife Supply Co.) and stored in polyethylene bottles that had been soaked in dilute $\mathrm{HCl}$ and rinsed with deionized water. Immediately after collection samples were packed in ice and transported to Ann Arbor where they were stored at $4^{\circ} \mathrm{C}$. Subsamples for nutrient determinations were filtered through $0.4-\mu \mathrm{m}$
Nuclepore filters in the field and analyzed in Ann Arbor on the day of collection. Major ions were determined within 1 month.

Oxygen and temperature were measured with a YSI model 54 oxygen meter (Yellow Springs Instr. Co.). Field measurements of $\mathrm{pH}$ were made with a Beckman GS meter. Transparency was measured with a $20-\mathrm{cm}$ Secchi disk. Conductivity was determined with a Markson model 10 meter (Markson Sci. Co.).

Major ion analyses-Sodium, potassium, calcium, and magnesium were determined by atomic absorption spectrophotometry (Perkin Elmer 403). Aliquots and standards for calcium and magnesium contained lanthanum. Analyses for calcium and magnesium were repeated with the EDTA titration method (Mackereth et al. 1978). Chloride was measured by the automated thiocyanate procedure on an autoanalyzer (Environ. Can. 1974) and repeated with the mercuric nitrate titration (Am. Public Health Assoc. 1976). Sulfate was analyzed by the ion exchange method (Mackereth et al. 1978) and repeated using a turbidometric method with Hach reagents (SulfaVer IV: Hach Chem. Co.) and a precision spectrophotometer. Alkalinity was measured with the Gran titration (Mackereth et al. 1978). Before 1980 , alkalinity was determined by titrating subsamples with $0.2 \mathrm{~N} \mathrm{H}_{2} \mathrm{SO}_{4}$ (delivered by microburet) to the 5.1 end point using bromcresol green-methyl red as an indicator (Am. Public Health Assoc. 1975). The different methods for calcium, magnesium, chloride, sulfate, and alkalinity agreed within a few percent for those samples treated by two methods.

Nutrient and chlorophyll analysesPhosphorus and silica were measured using the phospho- and silico-molybdate complex methods (Strickland and Parsons 1972). Nitrate was determined by a modified cadmium reduction technique (Mackereth et al. 1978; Strickland and Parsons 1972). The phenol-hypochlorite method was used to measure ammonium (Strickland and Parsons 1972). Total iron was determined with a Hach reagent 
(FerroVer: Hach Chem. Co.) in conjunction with a precision spectrophotometer. Chlorophyll $a$. was determined fluorometrically (Strickland and Parsons 1972).

Chemical balance-All of the lake water and atmospheric deposition analyses reported are within 3.5\% (range $=0.5-$ $3.5 \%$ ) of chemical balance. Measured and calculated conductivities agreed within a few percent (using equivalent conductances and equations given in Reynolds 1978).

Evaporative concentration-One can estimate the evaporative concentration factor $\left(C_{s}\right.$, the number of times atmospheric deposition is concentrated in the watershed by evaporation and evapotranspiration) as follows: by constructing a complete hydrologic budget, by using chloride ion concentrations as a conservative tracer of the water itself, or by calculating $C_{s}$ from published values for mean annual precipitation and total annual unit runoff (Dillon and Rigler 1975). The first two techniques have been shown to give similar results (Eriksson 1960; Cleaves et al. 1970; Hemond 1980). I used only the last two procedures to estimate $C_{s}$ because constructing hydrologic budgets for seepage lakes is very difficult (see Winter 1978a,b, 1979). To calculate $C_{s}$ using $\mathrm{Cl}^{-}$as a tracer I divided the volume-weighted whole-lake $\mathrm{Cl}^{-}$concentration by the mean volume-weighted $\mathrm{Cl}^{-}$ concentration for atmospheric deposition (based on data collected over 14 months, see below).

Atmospheric deposition-Analyses for wet and dry atmospheric deposition at the National Atmospheric Deposition Program (NADP) collection site in Pellston, Michigan (J. R. Boyle, site supervisor), were obtained from the Illinois State Water Survey. Data for atmospheric deposition presented here are the volumeweighted mean concentration values for all the samples collected and analyzed between the day samples were first collected at Pellston (3 July 1979) and the day Weber Lake was last sampled (9 September 1980).

Whole-lake concentrations-Average volume-weighted wholc-lake concentra- tions were computed from chemical analyses of water samples collected at 1- or 2-m depth intervals and volumetric data obtained from a bathymetric map of the lake (Mich. Conserv. Dep. 1938). Volumetric data were corrected to account for the surface height of the lake at the time it was sampled.

Environmental setting-The watershed of Weber Lake is in the Hardwood and Pigeon River State Forests at the junction of Emmet, Charlevoix, and Cheboygen Counties. The soils are part of the Leelanau series. These are well drained, loamy sands formed on glacial moraines and till plains (Alfred et al. 1973). Carbonate minerals determined gravimetrically comprise $1.2 \%$ of the surface soil (by weight as $\mathrm{CaCO}_{3}$ ). The watershed (ca. $420 \mathrm{ha}$ ) is primarily forested, but it also contains a meadow, a pond (3.7 ha), and a closed Sphagnum bog (3.3 ha). The forest is typified by hardwoods, red pine, white pine, and hemlock.

Human disturbance in the watershed does not seem to have changed much in the past 30 years. The small campground at the north end of the lake is much the same as it was when Hooper (1954) conducted his study, and the few permanent structures in the watershed are no longer in use.

Weber Lake is in Cheboygen County $\left(45^{\circ} 18^{\prime} \mathrm{N}, 84^{\circ} 43^{\prime} \mathrm{W}\right)$ and is a soft-water seepage lake. It is at the lowest point in the surrounding terrain (altitude, $267 \mathrm{~m}$ ). The depth and area of the lake vary with hydrologic conditions. Hooper (1954) reported a surface area of 12.5 ha and a maximum depth of $12.5 \mathrm{~m}$. In recent years the maximum depth observed has varied between 11.0 and $12.2 \mathrm{~m}$. During summer stagnation the hypolimnion of the lake becomes completely anaerobic $\left(\mathrm{O}_{2}\right.$ is undetcctable and there is a faint smell of $\mathrm{H}_{2} \mathrm{~S}$ ).

Acid-base budget-The acid-base budget for this combined terrestrial-aquatic system was constructed from the inputoutput budget in equivalents. The net gain or loss of specific ions from water flowing through the system was calculated by subtracting the evaporation- 
corrected concentration value for atmospheric deposition (input) from the whole-lake concentration value (gross output). The whole-lake concentration is * considered to be representative of the chemical composition of water leaving the system via seepage through the lake basin.

Strict application of the first law of thermodynamics and the principle of electroneutrality (see Kern and Weisbrod 1967; Reuss 1977) permits calculation of the acid-base budget from the input-output budget. This is possible because changes in $\mathrm{pH}$ and alkalinity accompany the net gain and loss of specific ions from the water. Reuss (1977) discussed changes in acid-base balance brought about by biologically mediated transformations in the sulfur and nitrogen cycles. His work and that of others (Nye and Tinker 1977; Goldman and Brewer 1980) indicate that uptake of ions by plants directly affects the acid-base balance of a system. Cation uptake generates $\mathrm{H}^{+}$because the principle of electroneutrality requires that charge balance be maintained between plants and their environment. Similarly, anion uptake produces $\mathrm{OH}^{-}$.

In accord with the first law of thermodynamics the difference between the initial and final state of the system (measured here in terms of equivalent concentration) takes into account all of the chemical transformations (organic and inorganic) that have taken place within the system and is indepcndent of their sequence or path (see Kern and Weisbrod 1967, p. 37). Negative changes in chemical state are a measure of the net biological uptake (NBU) of ions from the system. NBU represents ionic and nonionic forms of a particular element stored or lost (via gaseous emissions) by the system. It equals the total biological uptake of a specific ion minus the quantity of that ion mineralized by decomposition and subsequently lost through output. NBU is a summary statistic that can be used to directly calculate net production of $\mathrm{H}^{+}$and $\mathrm{OH}^{-}$because, as a measure of the change in chemical state that occurs within the system, it encompasses all of the pro- cesses affecting $\mathrm{pH}$ and alkalinity (e.g. total biological uptake, bacterial nitrification, bacterial denitrification, aerobic decomposition, sulfate reduction, etc.). Changes in acid-base balance caused by uncharged chemical species entering and leaving the system (e.g. $\mathrm{N}_{2}, \mathrm{~N}_{2} \mathrm{O}, \mathrm{SO}_{2}$, etc.) are also taken into account through the calculation of NBU. Therefore if the NBU for $\mathrm{NO}_{3}^{-}$was one equivalent, one equivalent of $\mathrm{OH}^{-}$was produced. Similarly, if the NBU for $\mathrm{NH}_{4}^{+}$was one equivalent, one equivalent of $\mathrm{H}^{+}$was produced.

Positive changes in chemical state are the result of ions being added to the water of the system, in this case through chemical weathering.

The sulfur cycle-Sulfur enters and leaves this combined terrestrial and aquatic system as aqueous $\mathrm{SO}_{4}{ }^{2-}$ and gaseous $\mathrm{SO}_{2}$ (and other compounds). The uptake of $\mathrm{SO}_{4}{ }^{2-}$ by plants probably accounts for only a small fraction of the $\mathrm{OHI}^{-}$ produced in the system because plants contain comparatively little sulfur. Most of the $\mathrm{OH}^{-}$production (shown below as $\mathrm{HCO}_{3}{ }^{-}$) results from sulfate reduction by anaerobic bacteria according to the following representative equation (see Goldhaber and Kaplan 1974):

$$
\left[\mathrm{SO}_{4}{ }^{2-}\right]+2\left[\mathrm{CH}_{2} \mathrm{O}\right]=\left[\mathrm{H}_{2} \mathrm{~S}\right]+2\left[\mathrm{HCO}_{3}{ }^{-}\right]
$$

where $\mathrm{SO}_{4}{ }^{2-}$ is balanced by metal cations or hydrogen and $\mathrm{CH}_{2} \mathrm{O}$ is organic matter. When sulfate ions in the environment are balanced by metal cations such as $\mathrm{Ca}^{2+}$ and $\mathrm{Mg}^{2+}$ that do not readily take part in redox reactions in lakes, permanent alkalinity is produced. Metal cations that participate in redox reactions in the water column, such as ferrous iron, support bicarbonate alkalinity under reducing conditions. This alkalinity, however, is destroyed under oxidizing conditions when $\mathrm{FE}(\mathrm{OII})_{3}$ and similar compounds precipitate.

In Weber Lake and its watershed sulfate reduction is believed to occur in water-logged soils, the bog, anaerobic sediments in the pond, and in the anaerobic hypolimnion of the lake. Within this combined system $\mathrm{SO}_{2}$ may be hydrolyzed and oxidized to $\mathrm{H}_{2} \mathrm{SO}_{4}$. Sulfuric acid pro- 
Table 1. Chemistry of Weber Lake on 9 September 1980. Fe represents total iron. Because anaerobic conditions prevail at $8 \mathrm{~m}$, iron concentrations are considered to be in the ferrous state. Sum of positive charges $-\Sigma^{+}$; sum of negative charges- $-\Sigma^{-}$; not detectable $-\mathrm{ND}$. Data are in $\mu \mathrm{oq} \cdot \mathrm{liter}^{-1} \cdot \mathrm{NO}_{3}^{-}$was not detectable.

\begin{tabular}{cccccccccccc}
\hline \hline $\begin{array}{c}\text { Depth } \\
(\mathrm{m})\end{array}$ & $\mathrm{Ca}^{2+}$ & $\mathrm{Mg}^{2+}$ & $\mathrm{K}^{+}$ & $\mathrm{Na}^{+}$ & $\mathrm{Fe}$ & $\mathrm{NH}_{4}{ }^{+}$ & $\mathrm{HCO}_{3}{ }^{-}$ & $\mathrm{SO}_{4}{ }^{2}$ & $\mathrm{Cl}$ & $\Sigma^{+}$ & $\Sigma^{-}$ \\
\hline 0 & 146 & 70 & 12.0 & 8.5 & $\mathrm{ND}$ & $\mathrm{ND}$ & 138 & 75 & 15.2 & 236 & 228 \\
2 & 147 & 69 & 12.0 & 6.1 & ND & ND & 142 & 75 & 16.2 & 234 & 232 \\
4 & 147 & 71 & 12.2 & 7.0 & ND & ND & 141 & 71 & 15.5 & 237 & 227 \\
6 & 148 & 72 & 12.6 & 7.0 & ND & ND & 142 & 73 & 13.7 & 240 & 229 \\
8 & 204 & 76 & 14.1 & 8.7 & 6 & 26 & 265 & 77 & 16.6 & 335 & 359 \\
\hline
\end{tabular}

duced by this mechanism is not included in measurements of atmospheric deposition, but its effect on the acid-base balance of the system is accounted for when one calculates the NBU for sulfate.

\section{Results and discussion}

Limnological observations-In Weber Lake and its watershed $(\mathrm{pH}<8.3)$ measurcd alkalinity is almost entirely $\left[\mathrm{HCO}_{3}{ }^{-}\right]$. Alkalinity is defined as

$$
\begin{aligned}
\text { Alk }= & {\left[\mathrm{HCO}_{3}{ }^{-}\right]+2\left[\mathrm{CO}_{3}{ }^{2-}\right]+\left[\mathrm{OH}^{-}\right] } \\
& -\left[\mathrm{H}^{+}\right]+R
\end{aligned}
$$

where $R$ represents other anions, e.g. organic ligands, $\mathrm{PO}_{4}{ }^{3-}, \mathrm{B}(\mathrm{OH})_{4}{ }^{-}$, ionic aluminum species, etc. In this environment, $R$ appears to be an insignificant contributor to alkalinity, because acceptable chemical balance (for charge and conductivity) is obtained with the ionic species measured. Chemical analyses are given in Table 1. The lake water is unstained and at these circumncutral $\mathrm{pH}$ lcvels is unlikely to contain significant concentrations of organic ligands. Phosphate and silicate concentrations were very low (at $0 \mathrm{~m}, \mathrm{P}=0.5 \mu \mathrm{M} ; \mathrm{Si}=2 \mu \mathrm{M})$.

On 9 September 1980 temperatures $\left(21.7^{\circ}-23^{\circ} \mathrm{C}\right)$ and oxygen concentrations $\left(8.7-9.0 \mathrm{mg} \cdot\right.$ liter $\left.^{-1}\right)$ were fairly uniform in the epilimnion $(0-6.5 \mathrm{~m})$. The anaerobic hypolimnion began at $7.5 \mathrm{~m}$.

Long term changes in limnology-Over the past 30 years the alkalinity of Wcbcr Lake has about doubled (Table 2).

Since 1952, the planktonic biota of Weber Lake has changed from organisms characteristic of acid waters to species commonly found in alkaline waters (Al- mer et al. 1978). The cladocerans Polyphemus pediculus (L.) and Holopedium gibbernum Zaddach (Hooper 1954) have been replaced by Daphnia parvula Fordyce and Diaphanosoma leuchtenbergianum Fischer, while the dinoflagellates Peridinium wisconsiensi Eddy and Glenodinium sp. (Hooper 1954) have been replaced by another dinoflagellate and several other types of algae, e.g. Gymnodinium sp., Dinobryon sociale Ehr., Ankistrodesmus falcatus (Corda) Ralfs, etc. Table 2 docs not include all of the available alkalinity data for Weber Lake. The major ion analyses reported by Hooper (1954) were obtained from a state laboratory; they are inconsistent with Hooper's field observations and bear the chemical signature that water samples are

Table 2. Comparison of surface (Alk-S) and whole-lake (Alk-W, in $\mu \mathrm{eq} \cdot$ liter $^{-1}$ ) alkalinity values obtained for Weber Lake by Hooper (1954: H) with present observations (K: this study). Depth profiles for alkalinity, temperature $(T)$, and dissolved oxygen are available for each date. Equilibrium $\mathrm{CO}_{2}$ concentrations calculated for Hooper's data are somewhat higher than those expected for lake water in equilibrium with the atmosphere (R. H. Hesslein pers. comm.). F. F. Hooper (pers. comm.) is confident that his original alkalinity values were accurate.

\begin{tabular}{lllrrr}
\hline & $T\left({ }^{\circ} \mathrm{C}\right)$ & $\mathrm{pH}$ & Alk-S & Alk-W & Source \\
\hline 14 Aug 1950 & 22.2 & 6.6 & 60 & 87 & $\mathrm{H}$ \\
25 Jul 1951 & 21.1 & 6.2 & 80 & 83 & $\mathrm{H}$ \\
13 Aug 1952 & 22.2 & 6.4 & 80 & 83 & $\mathrm{H}$ \\
17 Jul 1979 & 24.0 & 8.1 & 160 & 180 & $\mathrm{~K}$ \\
24 Jul 1979 & 25.6 & 8.2 & 156 & 168 & $\mathrm{~K}$ \\
9 Sep 1980 & 23.0 & 7.2 & 138 & 160 & $\mathrm{~K}$ \\
\hline
\end{tabular}


Table 3. Acid-base budget in terms of alkalinity (Alk) for Weber Lake and its watershed. Concentrations are in $\mu \mathrm{eq} \cdot$ liter $^{-1}$ and except for atmospheric deposition $\left(P_{r}\right)$ all values are expressed as lake water concentrations (volume-weighted whole-lake averages). Measured lake water concentrations (gross output) are for 9 September 1980. Measured alkalinity value has been corrected for acid precipitation actually titrating the lake $\left(3.8 \mu \mathrm{eq} \cdot \operatorname{liter}^{-1} \mathrm{H}^{+}\right.$expressed as a lake water concentration). The underlined values of $\mathrm{H}^{+}$and $\mathrm{OH}^{-}$(or $\mathrm{HCO}_{3}^{-}$) are considered to result from sulfate reduction and the net biological uptake of anions and cations. [Alk]-calculated $=\left(\mathrm{\Sigma OH}^{-}-\mathrm{\Sigma} \mathrm{H}^{+}\right)$. Correction factor for evaporative concentration $\left(C_{s}\right)$ is 3.85 .

\begin{tabular}{|c|c|c|c|c|c|c|}
\hline \multirow[b]{2}{*}{ Ion } & \multirow[b]{2}{*}{$P_{r}$} & \multirow{2}{*}{$\begin{array}{c}\text { Input } \\
P_{r} \times C_{s}\end{array}$} & \multirow{2}{*}{$\begin{array}{c}\text { Gross output } \\
\text { (lake) }\end{array}$} & \multirow{2}{*}{$\begin{array}{c}\text { Net } \\
\text { gain/loss }\end{array}$} & \multicolumn{2}{|c|}{ Sources of acid and base } \\
\hline & & & & & $\mathrm{II}^{+}$ & $\mathrm{OH}^{-}$ \\
\hline $\mathrm{Ca}^{2+}$ & 11.1 & 42.7 & 1.56 & +113 & - & 113 \\
\hline $\mathrm{Mg}^{2+}$ & 3.4 & 13.1 & 71 & +57.9 & - & 57.9 \\
\hline $\mathrm{K}^{+}$ & 0.7 & 2.7 & 12.5 & +9.8 & - & 9.8 \\
\hline $\mathrm{Na}^{+}$ & 7.6 & 29.3 & 7.2 & -22.1 & 22.1 & - \\
\hline $\mathrm{NH}_{4}^{+}$ & 17.2 & 66.2 & 4.1 & -62.1 & 62.1 & - \\
\hline $\mathrm{H}^{+}$ & 41.1 & 158.2 & 0.11 & -158 & $(\overline{158})^{*}$ & - \\
\hline $\mathrm{HCO}_{3-}^{-}$ & 0.0 & 0.0 & 164 & +164 & - & - \\
\hline $\mathrm{NO}_{3}^{-}$ & 27.0 & 104.0 & 0.0 & -104 & - & $\underline{104}$ \\
\hline $\mathrm{SO}_{4}{ }^{2-}$ & 55.0 & 211.8 & 74 & -138 & - & $\underline{138}$ \\
\hline $\mathrm{Cl}^{-}$ & 4.0 & 15.4 & 15.4 & 0.0 & - & - \\
\hline $\begin{array}{l}\Sigma \mathrm{H}^{+} \\
\Sigma \mathrm{OH}^{-}\end{array}$ & & & & & 242 & 423 \\
\hline [Alk]-calculated & & & 181 & & & \\
\hline [Alk]-measured & & & 164 & & & \\
\hline
\end{tabular}

* $\mathrm{H}^{+}$from atmospheric deposition.

known to acquire from acid-washed glass bottles. These data for bicarbonate alkalinity $\left(0 \mathrm{~m}=29.5 \mu \mathrm{eq} \cdot\right.$ liter $\left.^{-1}\right)$ have not been included in Table 2 . Between fall 1972 and summer 1974, Weber Lake was sampled seven times as part of a survey of 38 lakes in northern lower Michigan by Gannon and Paddock (1974) and Gannon (unpubl.). Because they titrated their samples to the pH 4.5 end point I have corrected their data by subtracting 32 $\mu \mathrm{eq} \cdot$ liter $^{-1}$ from each value as recommended by Henriksen (1979). They found corrected surface alkalinities from 143$248 \mu \mathrm{eq} \cdot$ liter $^{-1}$. These data are probably still overestimates, but sufficient information is not available to check their veracity.

Weber Lake is somewhat more eutrophic than it was in the 1950s (i.e. it has gone from oligotrophic to mesotrophic). In July-August 1979 I observed pronounced metalimnetic chlorophyll and oxygen maxima $\left(\mathrm{Chl} a=75 \mathrm{mg} \cdot \mathrm{m}^{-3}\right.$ at 8 $\mathrm{m} ; \mathrm{O}_{2}=11.4 \mathrm{mg} \cdot$ liter $^{-1}$ or $110 \%$ of saturation at $5 \mathrm{~m}$ ) not previously described by
Hooper (1954). Midsummer Secchi disk readings have also decreased from about $6 \mathrm{~m}$ to $3-4 \mathrm{~m}$.

The acid-base budget-The acid-base budget (in terms of alkalinity) is given in Table 3 . The concentration of $\mathrm{H}^{+}$resulting from acid deposition and the net biological uptake of cations in this system exactly equals the concentration of $\mathrm{OH}^{-}$ produced by sulfate reduction and the net biological uptake of anions. In other words, as Hemond (1980) has shown for Thoreau's Bog $(\mathrm{pH}=3.8)$, the net alkalinity produced by biological transformations (biotic $\mathrm{OH}^{-}$production minus biotic $\mathrm{H}^{+}$production) is equal in magnitude, but not in sign, to the $\mathrm{H}^{+}$entering the system as atmospheric deposition. Hemond argues that this equality is not coincidental and reflects the chemical composition of atmospheric deposition in that most of the hydrogen ions are balanced by nitrate and sulfate ions. Because externally derived $\mathrm{H}^{+}$concentrations are neutralized, the alkalinity remaining in the system appears to be that 
produced by the chemical weathering of carbonate and silicate minerals in the soil.

Whole-lake chemistry data comparable to those presented in Table 3 were also obtained for 17 July 1979. Recalculation of the acid-base budget by substituting these data for the 1980 data gives results that are similar to those shown in Table 3. Because data for atmospheric deposition were not available before July 1979 I have not presented a formal acid-base budget using the 1979 data.

The data presented in Table 3 indicate that sodium is being retained in this combined terrestrial-aquatic system. This is not commonly observed in predominantly terrestrial watersheds (Likens et al. 1977), even though Gjessing et al. (1976) investigated a number of watersheds where sodium was retained. Because aquatic plants contain considerably more sodium than terrestrial plants (Jordan et al. 1974; Hutchinson 1975) it is likely that sodium is being stored as living and dead vegetation in the aquatic portion of the system. The loss of potassium from a watershed is also uncommon (Likens et al. 1977), but it may occur more often in a combined terrestrial-aquatic system such as this one.

The relatively good agreement shown in Table 3 between the calculated and measured values for alkalinity indicates that most of the sources and sinks of alkalinity in this system have been taken into account.

Critique of method and proceduresEven though the data used to construct the acid-base budget are seemingly straightforward, internally consistent, balanced chemically, and in accord with the available literature, they can only be considered as an approximation of the actual values because a detailed on-site temporal investigation was beyond the scope of this study. It was not possible to estimate quantitatively most of the identifiable sources of error, but they can be qualitatively discussed. It is my impression that none of the potential errors is so large as to significantly alter the major conclusions presented.

The NADP collection site for atmo- spheric deposition is $30 \mathrm{~km}$ north of Weber Lake. The hierarchical order of anions and cations (by concentration) in atmospheric deposition is unlikely to change over such a short distance, because even atmospheric precipitation data collected in New Hampshire (Likens et al. 1977) have a similar chemical composition. Small differences in total concentration between the two sites are expected, but these differences are an integral part of the problem of estimating evaporative concentration within the watershed (see below). Because of aerial suspension of road salt $(\mathrm{NaCl})$, the chloride ion concentrations are potentially the most variable; however, few roads in this region are salted. Kerr (1981) reported that NADP and other dry deposition data are not particularly reliable. Fewer than 3\% of the samples used to calculate atmospheric deposition were for dry deposition. Other investigators have used atmospheric precipitation data collected at distances considerably $>30 \mathrm{~km}$ from their study site (Hemond 1980).

Estimating evaporative concentration is difficult even under ideal conditions. The actual $C_{s}$ value for this combined system is probably between 2.3 (calculated from runoff statistics; Pentland 1968; USGS Water Data Rep. Mi-1979-1) and 3.85 (determined by the $\mathrm{Cl}^{-}$balance procedure). Recalculation of the data presented in Table 3 using $C_{s}=2.3$ gives a valuc of $179 \mu \mathrm{eq} \cdot$ liter $^{-1}$ for [Alk]-calculated. This indicates that use of the lower $C_{s}$ value produces almost no change in the calculated alkalinity. The larger value $\left(C_{s}=3.85\right)$ was used to construct the acid-base budget in Table 3 because the observed changes in $\mathrm{Cl}^{--}$concentration reflect evaporative processes that have actually taken place in the combined system at Weber Lake, assuming, of course, that sources of $\mathrm{Cl}^{-}$within the drainage basin are unimportant. The loamy sands of the watershed are not known to contain any chloride-rich minerals (e.g. hornblende: J. R. Boyle pers. comm.). Road salt is a potential source of $\mathrm{Cl}^{\cdots}$, but although the county road that runs for 100 $m$ or so along the east side of the wa- 
tershed may have been salted in the past, the Cheboygen County Road Department (pers. comm.) claims that this is unlikely. The $C_{s}$ values Hemond (1980) reported for Thoreau's Bog $\left(C_{s}=4.9-6.0\right)$ are even higher than the value used here.

In constructing the acid-base budget of Weber Lake for 9 September 1980 I have used the mean volume-weighted atmospheric deposition data for the previous 14 months. This is not unreasonable because the residence time of the water in the lake is about 1 year (calculated with appropriate data for 1979-1980 and $C_{s}=$ 3.85). Recalculation of Table 3 using atmospheric deposition data for 12 months (11 September 1979-9 September 1980) changes the results only slightly.

Sources of alkalinity-Alkalinity in this system appears to have increased as an indirect consequence of acid precipitation. If acid precipitation lowered the average $\mathrm{pH}$ of the soil by as little as a few tenths of a $\mathrm{pH}$ unit, significant changes in the dissolution rate of carbonate minerals would occur. The water in the system is undersaturated with respect to calcite (and presumably to dolomite). The degree of undersaturation can be estimated with equations given by Stumm and Morgan (1970, p. 182) and the following data: mean annual temperature $=$ $5^{\circ} \mathrm{C}$, and $\mathrm{pCO}_{2}=0.0016 \mathrm{~atm}$ (Drake 1980; Reardon et al. 1979; for a dilute solution such as this unit activities were assumed). Bicarbonate ion concentrations in Weber Lake were 32 times less than expected in the 1950s and they are 16 times less at present. Recent studies of calcite dissolution under laboratory conditions (Plummer et al. 1979) indicate that dissolution rates are highly dependent on $\mathrm{pH}$ and $\mathrm{H}_{2} \mathrm{CO}_{3}$ concentrations. Alfred et al. (1973) reported pHI values between 5.6 and 6.0 for the soil-water zone of soils in the Leelanau scrics; most calcite weathering is believed to take place in the soilwater zone (Reardon et al. 1979). Plummer et al. (1979) showed that small decreases in $\mathrm{pH}$ within this range can more than double the rate of calcite dissolution. They also found that below pH 5 dissolution rates increase sharply. There- fore, it seems likely that acid precipitation has lowered the $\mathrm{pH}$ of the soil-water zone and thus increased the rate at which carbonate minerals are weathered. In this $\mathrm{pH}$ range higher alkalinities are a product of higher rates of carbonate weathering.

If the $\mathrm{pH}$ of the soil-water zone ever falls below 5 , the following generalized reaction may occur:

$$
\begin{aligned}
& \mathrm{CaCO}_{3(\mathrm{~s})}+2 \mathrm{H}^{+}+\mathrm{SO}_{4}{ }^{2-} \\
& \quad=\mathrm{SO}_{4}{ }^{2-}+\mathrm{Ca}^{2+}+\mathrm{CO}_{2(\mathrm{~g})}+\mathrm{H}_{2} \mathrm{O}
\end{aligned}
$$

(this equation could also be written for nitric acid). This reaction does not produce alkalinity. However, alkalinity may eventually be produced elsewhere in the system as a consequence of sulfate reduction or nitrate uptake by plants.

Weathering rates could also vary as a result of changes in climate, hydrology, or both (Gorham 1961). The climate of Weber Lake is generally the same as that of 30 years ago. Annual precipitation during the time of this study $(64-101 \mathrm{~cm}$. $\mathrm{yr}^{-1}$ : Mich. Dep. Agric. pers. comm.) and that of Hooper (68-103 $\mathrm{cm} \cdot \mathrm{yr}^{-1}$ : Mich. Dep. Agric. 1974) had similar wide ranges, but the alkalinity of the lake was not noticeably affected (see Table 1). The hydrology of the watershed could also be modified by changes in land use such as extensive logging or road construction. These activities might alter drainage patterns or change the runoff characteristics of the watershed (by increasing or decreasing evapotranspiration). Hydrologic changes can affect weathering rates by changing the $\mathrm{CO}_{2}$ concentration of the soil, the position of the water table, and the extent of the leached zone (see Reardon et al. 1980; Reardon pers. comm.). However, there have been no major changes in land use in the Weber Lake watershed between the time of Hooper's investigation and the present.

Weber Lake, like many seepage lakes elsewhere, is underlain by a regional aquifer containing hard groundwater (Hooper 1954; Hutchinson 1957). Mixing of this groundwater with the soft waters of the lake and its watershed would un- 
doubtedly increase the alkalinity of the system. However, there is no chemical evidence of mixing and the alkalinity of the hard groundwater has not changed (ca. $3.6 \mathrm{meq} \cdot$ liter $^{-1}$; Hooper 1954; this study).

Alkalinity and eutrophication-Increases in alkalinity can markedly affect aquatic ecosystems. It is known that alkalinity, internal phosphorus loading, primary production, and fish yield are positively correlated. Because $\mathrm{pH}$ is the master variable controlling acid-base equilibria, increases in alkalinity that increase the equilibrium $\mathrm{pH}$ of an aquatic ecosystem affect the chemical equilibria of other ionic species. Hayes and Phillips (1958) proposed that a dynamic equilibrium exists between phosphorus associated with the solid phase of the sediment (most of the phosphorus) and phosphorus in the aqueous phase (lake water and porewater). In a companion paper MacPherson et al. (1958) demonstrated that the availability of phosphorus from lake sediment is $\mathrm{pH}$-dependent. Increasing amounts of phosphorus become available as $\mathrm{pH}$ increases above (or decreases below) about 5.5 (reviewed in Stumm and Morgan 1970). In other words, the internal phosphorus loading of lakes is a $\mathrm{pH}$-dependent parameter. The strong positive relationship among phosphorus loading, primary productivity, and eutrophication is reviewed in a general way by Wetzel (1975). The positive correlation between rates of primary productivity and fish yield is discussed by Melack (1976). The equilibrium $\mathrm{pH}$ of Weber Lake has only increased by about $0.5 \mathrm{pH}$ units, but the internal phosphorus loading could easily have doubled (see MacPherson et al. 1958).

Whole-lake alkalization experiments (Waters 1957; Stross and Hasler 1960) where lime was added to undisturbed lakes in northern Michigan and Wisconsin produced changes in the biota similar to those observed at Weber Lake, in addition to making the lakes more eutrophic.

Acid precipitation can also increase internal phosphorus loading in lakes (either acidic or basic) that contain habitats con- ducive to the growth of sulfate-reducing bacteria. Sulfate-reducing bacteria in freshwater are often limited by sulfate, and acid precipitation falling on an ecosystem containing reducing environments can therefore increase rates of sulfate reduction. This occurs because sulfate is the major anion in acid precipitation. Schindler et al. (1980) and Kelly et al. (1982) observed that rates of sulfate reduction increased as sulfate concentrations increased in a whole-lake experiment involving the addition of sulfuric acid. The amount of sulfate reduced should also be higher in productive lakes, because sulfate-reducing bacteria require both strongly reducing conditions and various organic substrates (e.g. pyruvate, lactate, etc.: Badziong et al. 1978). The strong positive relationships among $\mathrm{H}_{2} \mathrm{~S}$ production, metal sulfide precipitation, and internal phosphorus loading have been firmly established (Wetzel 1975). The precipitation of metal sulfides liberates phosphorus from sediments. Sulfate reduction, of course produced $\mathrm{H}_{2} \mathrm{~S}$ and $\mathrm{OH}^{-}$. This increases the alkalinity of the hypolimnion.

\section{Conclusions}

At Weber Lake in Michigan and Thoreau's Bog in Massachusetts alkalinity production resulting from nitrate uptake by plants and sulfate reduction by bacteria is sufficient to neutralize acid precipitation (including biologically mediated hydrogen ion production). Because acid precipitation in both systems is neutralized as a consequence of biological transformations involving the major anionic components of acid precipitation itself, acid precipitation has not directly affected the acid-base balance of either the acid bog or the circumneutral lake. However, at Weber Lake acid precipitation appears to have increased the rate at which minerals are weathered in the soil. This has led to a doubling of the lake's alkalinity in the past 30 years.

I suspect that the differences in buffering capacity ascribed to sensitive and nonsensitive regions are largely a function of the prevalence of reducing envi- 
ronments in each. Reducing environments should be more common in lakes and other aquatic ecosystems that have received higher phosphorus loadings over recent geologic time because of greater primary production and the accumulation of organic sediments. Lakes in sensitive regions have probably received comparatively little phosphorus over recent geologic time while those in nonsensitive regions have received more. Igneous rocks contain slightly more phosphorus than calcareous rocks, but they are weathered much less rapidly (McKelvey 1973).

These observations indicate that one should be able to restore an acidified lake (containing excess concentrations of $\left.\mathrm{SO}_{4}{ }^{2-}\right)$ to its original level of acidity, and maintain that level for a considerable length of time, by creating strongly reducing environments in the sediments and at least seasonally in the hypolimnion. This could be done by pumping artificial sediments rich in organic matter and metal oxides (such as iron) into the bottom of the lake. Permanent alkalinity is produced as a result of metal sulfide precipitation (Schindler et al. 1980; Goldhaber and Kaplan 1974). If the lake was strongly acidified, liming might be required initially to bring the $\mathrm{pH}$ of the sediments up to the optimal $\mathrm{pH}$ of sulfate-reducing bacteria (see Badziong and Thauer 1978). However, this may not be a problem if naturally occurring strains of sulfate-reducing bacteria with low pH optima are present. Restoring an acidified lake in this manner is not without its problems. The creation of strongly reducing conditions within a lake increases the availability of phosphorus (see above) and the lake would probably become more eutrophic than it was originally. Reducing environments in some lakes could also be created by heavy fertilization (mainly with phosphorus), but this process would require considerable time. In sensitive regions eutrophic lakes should be the least susceptible to acidification.

Even though I have only studied one lake I believe that lake alkalization as a consequence of acid precipitation may be a common phenomenon. However, the effects of alkalization (i.e. eutrophication) will be most pronounced in soft-water lakes and diminish in hard waters near or at saturation with respect to $\mathrm{CaCO}_{3}$. Once saturation with respect to $\mathrm{Ca}_{5} \mathrm{OH}\left(\mathrm{PO}_{4}\right)_{3}$ (hydroxyapatite) and $\mathrm{CaCO}_{3}$ is reached, phosphorus concentrations will decrease, owing to direct precipitation in the case of the former mineral and coprecipitation in the case of the latter (Stumm and Morgan 1970; Wetzel 1975). When this happens lakes may again become somewhat less eutrophic.

The processes described here suggest that streams and surface groundwaters from watersheds containing calcareous substrates and reducing environments (water-logged soils, bogs, and reduced sediments) have increased in alkalinity as a result of increasingly acidic precipitation. The alkalinities of most lakes in the lower peninsula of Michigan are probably unaffected by the increased alkalinities of their influents because these lakes (alkalinities of drainage lakes range generally between 2 and $4 \mathrm{meq} \cdot$ liter $^{-1}$ : Hooper 1956; Schneider 1975) are influenced by hard regional groundwaters and are at or near saturation with respect to $\mathrm{CaCO}_{3}$. The soft-water seepage lakes in this part of Michigan, however, are perched above the hard regional groundwater and thus register the affects of acid precipitation.

In Wisconsin more than 180 predominantly soft-water lakes that were originally studied by E. A. Birge and C. Juday have recently been revisited. Most of the lakes have increased in $\mathrm{pH}$, alkalinity, and conductivity over the past 50 years (Eilers and Webster in prep.; Bowser et al. in prep.). Some of the observed increases in $\mathrm{pH}$ and alkalinity may be due to various changes occurring in individual watersheds (i.e. logging, reforestation, additional homes, etc.). However, increases in $\mathrm{pH}$ and alkalinity similar to those in Weber Lake were also found for seepage lakes in undisturbed watersheds.

The acid-base budget presented here represents a new type of limnological analysis, even though acid-base budgets 
have recently been published for a forested ecosystem (Sollins et al. 1980) and a Sphagnum bog (Hemond 1980). I am convinced that this type of analysis must be used if we are to understand not only acid-base relationships, but also the biogeochemical cycling of sulfur and nitrogen in most ecosystems. Constructing acid-base budgets also demonstrates that it is absolutely essential to obtain chemically balanceable analyses for the aqueous components of the system under investigation. It is also important that all chemical concentrations be expressed in equivalents. Weight units are particularly unfortunate because they have little chemical meaning and can prevent an investigator from recognizing stoichiometric changes in a system.

It is my impression that the effects of acid precipitation on lakes are more widespread and complicated than previously assumed. Soft-water lakes seem to be particularly susceptible to the effects of anthropogenic mineral acids. In sensitive regions soft-water lakes are subject to acidification and in nonsensitive regions, alkalization. Both processes change the species composition, but acidification kills fish while alkalization makes lakes more eutrophic. Unfortunately, neither is a desirable result.

\section{References}

Alfred, S. D., A. G. Hyde, and R. L. Larson. 1973. Soil survey of Emmet County, Michigan. U.S. Dep. Agric.

Almel, B., W. Dickson, E. Ekstr $\emptyset$ M, AND E. I $\emptyset$ RNSTR $\emptyset$ M. 1978. Sulfur pollution and the aquatic ecosystem, p. 273-311. In J. Nriagu [ed.], Sulfur in the environment, part 2. Wiley.

AMERICAN PUBlic Health Association. 1976. Standard methods for the examination of water and wastewater, 14th ed.

BADZIONG, W., AND R. K. THAUER. 1978. Growth yields and growth rates of Desulfovibrio vulgaris (Marburg) growing on hydrogen plus sulfate and hydrogen plus thiosulfate as the sole energy sources. Arch. Microbiol. 117: 209-214.

- $\longrightarrow$, AND J. G. ZEIKUS. 1978. Isolation and characterization of Desulfovibrio growing on hydrogen plus sulfate as the sole energy source. Arch. Microbiol. 116: 41-49.

BEAMISH, R. J., W. L. LOCKHART, J. C. VANI OON, AND H. H. HARVEY. 1975. Long-term acidification of a lake and resulting effects on fishes. Ambio 4: 98-102.
Cleaves, E. T., A. E. Godfrey, and O. P. BrickER. 1970. Geochemical balance of a small watershed and its geomorphic implications. Geol. Soc. Am. Bull. 81 : 3015-3032.

COGBILL, C. V., AND G. E. LIKENS. 1974. Acid precipitation in the Northeastern United States. Water Resour. Res. 10: 1133-1137.

Dillon, P. J., AND F. H. Rigler. 1975. A simple method for predicting the capacity of a lake for development based on lake trophic status. J. Fish. Res. Bd. Can. 32: 1519-1531.

Docilnger, L. S., AND T. A. Siliga [Eds.]. 1976. Acid precipitation and the forest ecosystem. Proc. 1st Int. Symp. U.S. Dep. Agric.

DRAKE, J. J. 1980. The effect of soil activity on the chemistry of carbonate groundwaters. Water Resour. Res. 16: 381-386.

Environment CANADA. 1974. Analytical methods manual. Inland Waters Dir.

ERIKSSON, E. 1960. The yearly circulation of chloride and sulfur in nature: Meteorological, geochemical, and pedological implications. Part 2. Tellus 12: 63-109.

Gannon, J. E., ANd M. W. Paddock. 1974. Investigations into ecological and sociological determinants of land-use decisions-A study of inland lake watersheds in northern Michigan. Univ. Mich. Biol. Sta. Tech. Rep. 1. 276 p.

Gjessing, E. T., A. Henriksen, M. Johannessen, AND R. F. WRIGHT. 1976. Effects of acid precipitation on freshwater chemistry, p. 65-85. In F. H. Braekke [ed.], Impact of acid precipitation on forest and freshwater ecosystems in Norway. SNSF-Proj. Rep. Oslo.

GoldhaBER, M. B., AND I. R. KaPlan. 1974. The sulfur cycle, p. 569-655. In E. D. Goldberg [ed.], The sca, v. 5. Interscience.

Goldman, J. C., AND P. G. Brewer. 1980. Effect of nitrogen source and growth rate on phytoplankton-mediated changes in alkalinity. Limnol. Oceanogr. 25: 352-357.

GORHAM, E. 1961. Factors influencing supply of major ions to inland waters, with special reference to the atmosphere. Geol. Soc. Am. Bull. 72: 795-840.

Hayes, F. R., AND J. E. PHILLIPS. 1958. Lake water and sediment. 4. Limnol. Oceanogr. 3: 459-475.

HEMOND, H. F. 1980. Biogeochemistry of Thoreau's Bog, Concord, Massachusetts. Ecol. Monogr. 50: 507-526.

HENRIKSEN, A. 1979. A simple approach for identifying and measuring acidification of freshwater. Nature 278: 542-545.

HoOPER, F. F. 1954. Limnological features of Weber Lake, Cheboygen County, Michigan. Pap. Mich. Acad. Sci. 39: 229-240.

- 1956. Some chemical and morphometric characteristics of southern Michigan lakes. Pap. Mich. Acad. Sci. 41: 109-130.

Hutchinson, G. E. 1957. A treatise on limnology, v. 1. Wiley.

—_ 1975. A treatise on limnology, v. 3. Wiley.

Jordan, P. A., D. B. Botkin, A. S. Dominski, H. S. LOWENDORF, AND G. E. BEI ovsky. 1974. Sodium as a critical nutrient for the moose of 
Isle Royale. Proc. N. Am. Moose Conf. Workshop 9: 13-42.

Kelly, C. A., J. W. Rudd, R. B. CoOK, AND D. W. SCIIINDLER. 1982. The potential importance of bacterial processes in regulating the rate of lake acidification. Limnol. Oceanogr. 27: 868882.

KerN, R., AND A. WeisBrod. 1967: Thermodynamics for geologists. Freeman Cooper.

KERR, R. A. 1981. There is more to "acid rain" than rain. Science 211: 692-693.

Likens, G. E. 1976. Acid precipitation. Chem. Eng. News 54: 29-44.

, F. H. Bormann, R. S. Pierce, J. S. Eaton, AND N. M. JoHNSON. 1977. Biogeochemistry of a forested ecosystem. Springer.

$\longrightarrow$, R. F. WRight, J. N. Galloway, and T. J. Butler. 1979. Acid rain. Sci. Am. 241: 4351.

MCKELVEY, V. E. 1973. Abundance and distribution of phosphorus in the lithosphere, p. 13 31. In E. J. Griffith et al. [eds.], Environmental phophorus handbook. Wiley.

Mackereth, F. J., J. Heron, AND J. F. TALling. 1978. Water analysis: Some revised methods for limnologists. Freshwater Biol. Assoc. Sci. Publ. 36. 120 p.

MacPherson, L. B., N. R. Sinclair, AND F. R. HAYES. 1958. Lake water and sediment. 3. Limnol. Oceanogr. 3: 318-326.

MELACK, J. M. 1976. Primary productivity and fish yields in tropical lakes. Trans. Am. Fish. Soc. 105: 575-580.

Micimgan Conservation Department. 1938. Lake inventory map-Weber Lake. Inst. Fish. Res.

Michigan Department of AGRICULTURe. 1974. Climate of Michigan by stations, 2nd ed. Mich. Weather Serv.

Nye, P. II., AND P. B. Tinker. 1977. Solute movement in the soil-root system. Univ. Calif.

Pentland, R. L. 1968. Runoff characteristics in the Great Lakes Basin. Proc. 11th Conf. Great Lakes Res. 1968, p. 326-359.

Plummer, L. N., D. L. PARKhurst, and T. M. WIGLEY. 1979. Critical review of the kinetics of calcite dissolution and precipitation, p. 537573. In Chemical modeling in aqueous systems. Am. Chem. Soc. Symp. 93.

Reardon, E. J., G. B. Allison, AND P. FrITz: 1979. Seasonal chemical and isotopic variations of soil $\mathrm{CO}_{2}$ at Trout Creek, Ontario. J. Hydrol. 43: 355371 .
A. A. Mozeto, And P. Fritz. 1980. Recharge in northern clime calcareous sandy soils: Soil water chemical and carbon-14 evolution. Geochim. Cosmochim. Acta 44: 1723-1735.

Reuss, J. O. 1977. Chemical and biological relationships relevant to the effect of acid rainfall on the soil-plant system. Water Air Soil Pollut. 7: 461-478

ReyNOLDS, R. C. 1978. Polyphenol inhibition of calcite precipitation in Lake Powell. Limnol. Oceanogr. 23: 585-597.

SciIndler, D. W., R. Wagemann, R. B. CoOK, T. Ruszczynski, AND J. Prokopowich. 1980. Experimental acidification of Lake 223, Experimental Lakes Area: Background data and the first three years of acidification. Can. J. Fish. Aquat. Sci. 3 7: 342-354.

SCHNEIDER, J. C. 1975. Typology and fisheries potential of Michigan lakes. Mich. Acad. 8: 5984.

SCHOFIELD, C. L. 1976. Acid precipitation: Effects on fish. Ambio 5: 228-230.

Sollins, P., C. C. Grier, F. M. McCorison, K. Cromack, AND R. Fogel. 1980. The internal element cycles of an old-growth Douglas-fir ecosystem in western Oregon. Ecol. Monogr. 50: 261-285.

STRICKLAND, J. D., AND T. R. Parsons. 1972. A practical handbook of seawater analysis, 2nd ed. Bull. Fish. Res. Bd. Can. 167.

Stross, R. G., AND A. D. Hasler. 1960. Some lime-induced changes in lake metabolism. Limnol. Oceanogr. 5: 265-272.

Stumm, W., and J. J. Morgan. 1970. Aquatic chemistry. Wiley.

WATERS, T. F. 1957. The effects of lime application to acid bog lakes in northern Michigan. Trans. Amn. Fish. Soc. 86: 329-344.

Wetzel, R: G. 1975. Limnology. Saunders.

Winter, T. C. 1978a. Numerical simulation of steady state three-dimensional groundwater flow near lakes. Water Resour. Res. 14: 245-254. - 1978b. Ground-water component of lake water and nutrient budgets. Int. Ver. Theor. Angew. Limnol. Verh. 20: 438-444.

- 1979. The role of groundwater in lakewater balances, p. 5-29. In Proc. Lake Management Conf. Univ. Conn.

Submitted: 26 March 1981 Accepted: 1 April 1982 